\title{
SUMUR RESAPAN KOMUNAL PENDUKUNG SANITASI LINGKUNGAN RW XI, DESA JATEN, KECAMATAN JATEN, KABUPATEN KARANGANYAR
}

\author{
Budi Legowo $^{1}$, Iwan Yahya ${ }^{1}$, Darsono ${ }^{1}$, Daru Wahyuningsih ${ }^{2}$ \\ ${ }^{1}$ Laboratorium Geofisika dan Akustik Fisika FMIPA UNS \\ ${ }^{2}$ Pusat Pengembangan Teknologi Informasi untuk Pembelajaran LPPMP UNS \\ pakbeel@staff.uns.ac.id
}

\begin{abstract}
Abstrak
Objek pengabdian Program Kemitraan Masyarakat berada di RT 05 / RW XI dan RT 06 / RW XI Perumahan Bumi Graha Indah Jaten Karanganyar. Terdapat \pm 72 kepala keluarga dengan tidak kurang dari 250 jiwa yang setiap harinya menghasilkan \pm 30.000 liter air limbah rumah tangga. Air limbah rumah tangga terbanyak berasal dari aktivitas mandi dan cuci. Metode pengabdian terdiri atas: analisis permasalahan mitra, penyusunan detail teknis, pembuatan sumur resapan dan penyusunan rencana tindak lanjut. Permasalahan utama di lingkungan masyarakat sasaran adalah buruknya sistem drainase yang menyebabkan genangan air limbah rumah tangga sehingga berpotensi menurunkan sistem sanitasi lingkungan. Solusi pemecahan masalah mitra adalah menyusun detail teknis ubahsuai siklus hidrologi pendek dan pembuatan sumur resapan komunal untuk menampung air limbah rumah tangga. Hasil evaluasi menunjukkan saluran inlet dan sumur resapan berfungsi dengan baik. Hal ini ditunjukkan dengan berkurangnya genangan pada sistem drainase dan air masuk dalam sistem sumur resapan. Sampah padat yang masuk dalam sistem drainase sering kali menyebabkan fungsi saluran inlet tidak berfungsi maksimal. Perlu dibuat bak kontrol saring sehingga sampah padat dapat dicegah masuk dalam sistem inlet. Pembuatan sumur resapan komunal pada perumahan teratur dapat dikembangkan dalam lingkup yang lebih luas sebagai salah satu upaya konservasi air tanah.
\end{abstract}

Kata Kunci : sumur resapan komunal, sanitasi, air limbah rumah tangga

\section{PENDAHULUAN}

Perumahan Bumi Graha Indah di Desa Jaten, Kecamatan Jaten Kabupaten Karanganyar masuk dalam kategori perumahan teratur di kota besar. Menurut data BPS Kabupaten Karanganyar tahun 2019, jumlah penduduk di Kecamatan Jaten tercatat sebanyak 82.000 jiwa, sehingga ada sekitar 9.600.000 liter air terbuang pada saluran terbuka perharinya. Terdapat \pm 72 kepala keluarga dengan tidak kurang dari 250 jiwa pada kelompok masyarakat sasaran PKM berada di RT 05 / RW XI dan RT 06 / RW XI Perumahan Bumi Graha Indah
Jaten Karanganyar. Perhitungan konsumsi air bersih 250 jiwa pada kelompok masyarakat sasaran PKM, setiap harinya menghasilkan \pm 30.000 liter air limbah rumah tangga (BPS, 2018).

Mencegah adanya genangan pada sistem pembuangan air limbah perumahan dengan mengaplikasikan teknologi sumur resapan secara komunal diharapkan dapat memperpendek siklus hidrologi sehingga dapat menjaga kelestarian air tanah sekaligus dapat mengurangi tempat tumbuh nyamuk pembawa penyakit yang berbahaya.

Lingkungan Hidup dan Kebencanaan 
Keberadaan air tanah di Kabupaten Karanganyar bervariasi mengikuti topografi setempat pada kedalaman antara 50 - 160 meter di bawah permukaan tanah. Kedalaman air tanah sangat dipengaruhi oleh pola eksplorasinya (Koesuma \& Sulastoro, 2016). Upaya konservasi air tanah dapat dilakukan dengan menjaga pola konsumsi, melestarikan daerah imbuhan (recharge area), memperluas daerah tangkapan (catchment area) dan memperpendek siklus hidrologi (Legowo \& Wahyuningsih,2016). Ubah suai siklus hidrologi dapat dilakukan dengan membuat sumur resapan setempat untuk menampung air limpasan limbah rumah tangga. Air limpasan rumah tangga yang berasal dari kegiatan domestik tidak dialirkan di sistem pembuangan, upaya ini dapat memperpendek siklus hidrologi (Legowo \& Darsono, 2017).

Seperti kebanyakan perumahan teratur di perkotaan, Perumahan Bumi Graha Indah Jaten Karanganyar memiliki sistem drainase yang kurang baik. Proses sedimentasi karena level ketinggian buangan yang tidak sempurna menyebabkan banyak genangan limbah rumah tangga dalam sistem pembuangan air limbah, seperti disajikan pada Gambar 1. berikut,
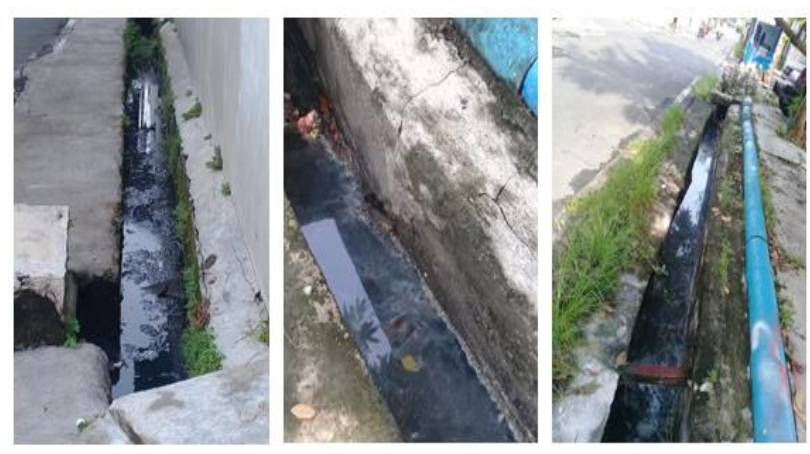

Gambar 1. Genangan pada sistem drainase lingkungan kelompok masyarakat sasaran

Genangan seperti pada Gambar 1. memiliki potensi digunakan sebagai tempat tumbuh nyamuk dewasa. Laporan suspect demam berdarah di Kabupaten Karanganyar ada sebanyak 535 kasus. Mayoritas kasus terjadi di Kecamatan Karanganyar, Tawangmangu, Tasikmadu, Jaten, Kebakkramat, dan Colomadu (Wardoyo, 2019)
Penutupan sistem drainase secara permanen memperburuk keadaan karena menyebabkan kontrol perawatan sulit dilakukan. Ilustrasi keadaan sanitasi lingkungan sistem drainase dalam sistem pembuangan air limbah disajikan pada Gambar 2. Berikut
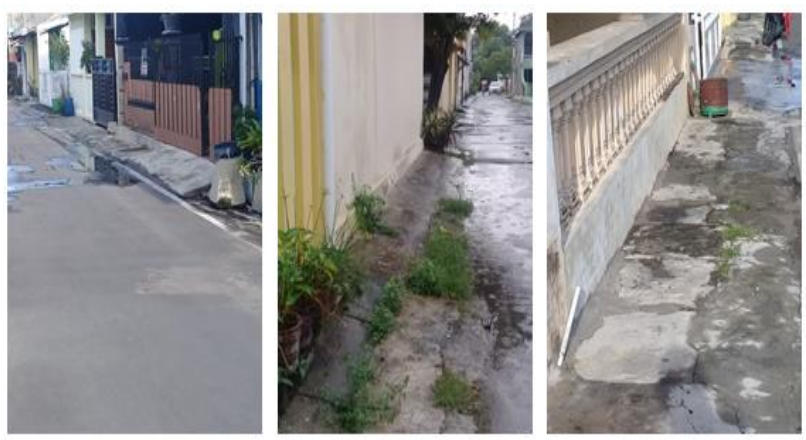

Gambar 2. Penutupan sistem drainase lingkungan kelompok masyarakat sasaran

Penutupan sistem drainase dilakukan dengan alasan kebersihan dan keindahan. Dampak lain dari penutupan sistem drainase adalah berkurangnya kemampuan mengalirkan air limpasan permukaan. Penutupan sistem drainase juga menyebabkan rawan sumbatan karena sampah dan pada gilirannya menyebabkan genangan lebih tinggi karena terhambat sedimentasi sulit dibersihkan (Eleonora, 2020).

\section{METODE}

Metode pengabdian terdiri atas: analisis permasalahan mitra, penyusunan detail teknis, pembuatan sumur resapan dan penyusunan rencana tindak lanjut.

Analisis permasalahan mitra dalam bentuk FGD dengan pokok materi penyampaian latar belakang masalah yang ada di lingkungan mitra, langkah teknis implementasi teknologi tepat guna dan manfaat peningkatan sanitasi lingkungan yang bisa didapatkan.

Penyusunan detail teknis berupa pembuatan rancangan secara detail berkait penempatan sumur resapan komunal, rancangan struktur sumur resapan komunal dan rancangan jaringan inlet dari sistem drainase terbuka. 
Pembuatan sumur resapan sesuai kesepakatan dari kegiatan penyusunan detail teknis. Jumlah dan penempatan sumur resapan komunal disesuaikan dengan kesepakatan mitra sasaran dan ketercukupan dana pengabdian.

Penyusunan rencana tindak lanjut dalam bentuk FGD dengan pokok materi penyusunan instrumen evaluasi keberhasilan program dan keterpenuhan daya guna sumur resapan komunal dalam meningkatkan sistem sanitasi lingkungan. Rencana tindak lanjut dibagi dalam dua kegiatan pelaksanaan evaluasi yang terdiri dari; 1). Evaluasi penyelesaian program, dan 2). Evaluasi efektifitas dan efisiensi fungsi sumur resapan komunal.

\section{HASIL DAN PEMBAHASAN}

Program Kemitraan Masyarakat dilaksanakan pada bulan Juni - Agustus 2020 dengan kelompok masyarakat sasaran di RT 05 / RW XI dan RT 06 / RW XI Perumahan Bumi Graha Indah Jaten Karanganyar. Kondisi jaringan drainase sebagai sistem pembuangan air limbah rumah tangga disajikan pada Gambar 3. Hampir 90\% sistem drainase di lingkungan masyarakat sasaran sudah ditutup dengan cor permanen. Ilustrasi lingkungan masyarakat sasaran seluruhnya sudah direnovasi secara penuh, sehingga pembuatan sumur resapan setempat tiap keluarga sulit dilakukan. Sumur resapan secara komunal merupakan solusi yang dapat dilakukan.

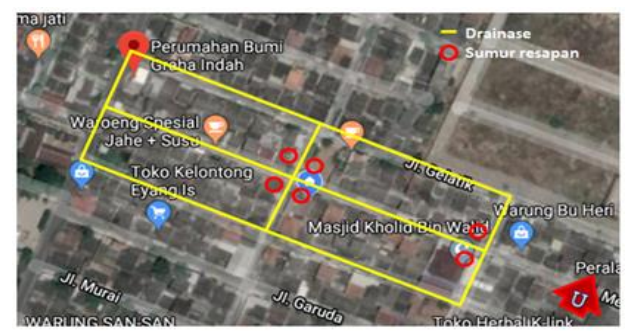

Gambar 3. Sistem drainase lingkungan kelompok masyarakat sasaran

Sistem penyaluran air limbah sistem komunal sangat cocok diterapkan di perumahan teratur. Mengarahkan limpasan ke dalam sumur resapan tertutup dapat meningkatkan sistem sanitasi lingkungan akibat bau dari limbah organik dari air limbah rumah tangga (Ulya \& Djoko Marsono, 2014). Teknologi sumur resapan seperti disajikan pada Gambar 4. dan Gambar 5., sekaligus berfungsi dalam memperpendek siklus hidrologi dan berperan dalam upaya konservasi air tanah (Legowo \& Wahyuningsih,2016).

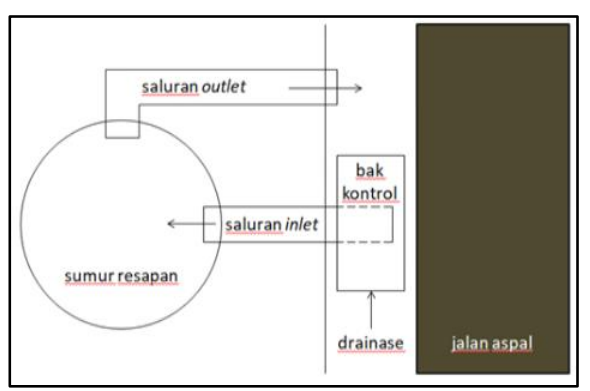

Gambar 4. Skema sumur resapan tampak atas

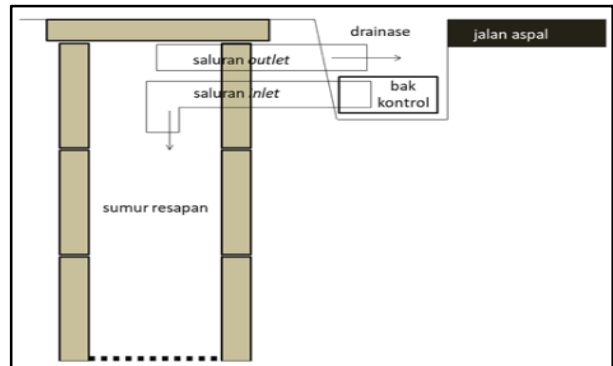

Gambar 5. Skema sumur resapan tampak samping

Pembuatan sumur resapan komunal difokuskan di fasilitas umum RT 05 dan RT 06, RW XI Perumahan Bumi Graha Indah Jaten Karanganyar. Sistem drainase sebagai saluran inlet seperti ditunjukkan pada Gambar 3 dilakukan pembersihan dari sampah yang menyangkut akibat kerusakan penutup karena terjadinya pelapukan.

Sumur resapan dibuat hingga kedalaman lapisan pasir ditemukan selama penggalian. Tujuannya adalah agar resapan dapat berfungsi dengan baik dan air resapan bisa ikut dalam proses imbuhan air tanah dangkal (Legowo \& Darsono, 2017). Tutup atas sumur dibuat rata tanah di atasnya dengan penutup beton sehingga tidak mengurangi fungsi penggunaan lahan.
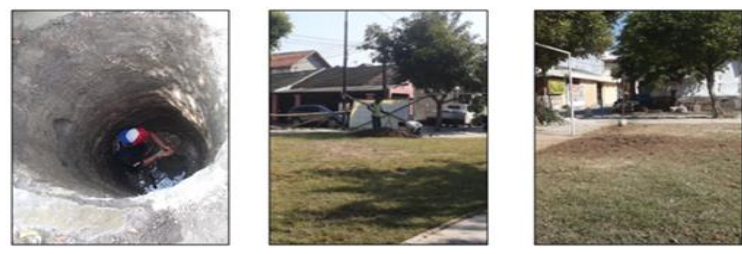
Gambar 6. Proses pembuatan sumur dan penutupan

Pemasangan inlet berupa pipa penghubung antara saluran drainase dan sumur resapan ditambahkan untuk membelokkan aliran air limbah buangan rumah tangga. Terdapat dua set sumur resapan dengan total 4 buah yang saling terhubung dengan saluran inlet paralon untuk memaksimalkan daya tampung sumur resapan.
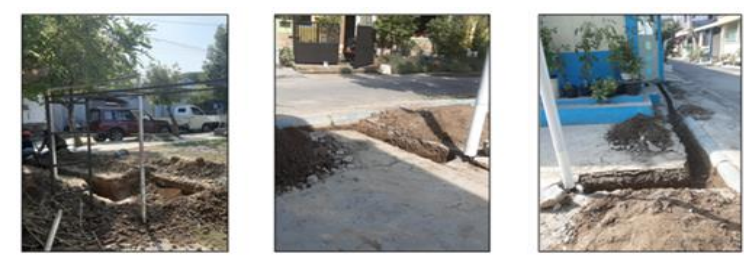

Gambar 7. Pemasangan inlet penghubung sumur

Pembuatan sumur resapan komunal dalam pengabdian ini dapat dengan mudah dikembangkan untuk perumahan teratur lainnya. Perlu dilakukan penyesuaian sistem drainase yang ada dengan memanfaatkan lahan terbuka (open space) sebagai daerah tangkapan (catchment area).

\section{SIMPULAN DAN SARAN}

Hasil pengamatan fungsi kerja sumur resapan komunal menunjukkan hasil yang baik. Hal ini ditunjukkan dengan saluran inlet yang berfungsi mengalirkan air limbah buangan rumah tangga dan sistem drainase yang senantiasa kering tanpa genangan.

Perlu dibuat bak kontrol saring sehingga sampah padat dapat dicegah masuk dalam sistem inlet agar fungsi kerja sumur resapan komunal lebih maksimal. Pembuatan sumur resapan komunal pada perumahan teratur dapat dikembangkan dalam lingkup yang lebih luas sebagai salah satu upaya konservasi air tanah.

\section{UCAPAN TERIMAKASIH}

Pengabdian dilaksanakan dalam skim Program Kemitraan Masyarakat (PKM) Lembaga Penelitian dan Pengabdian Masyarakat (LPPM) dana PNBP UNS tahun 2020.

\section{REFERENSI}

BPS. (2018). Kecamatan Jaten dalam Angka. Karanganyar: Balai Pusat Statistik.

Eleonora, P. (2020, Februari 2). https://jogja.suara.com/. Retrieved Februari 3 , 2020, from https://jogja.suara.com/: https://jogja.suara.com/read/2020/01/02/142 935/bupati-sleman-mau-tutup-selokanharus-lapor

Koesuma, S., \& Sulastoro. (2016). Identifying of Groundwater Level by Using Geoelectric Method in Karanganyar, Central Java, Indonesia. Journal of Physics: Conference Series, 31-36.

Legowo, B., \& Darsono. (2017). Ubah Suai Siklus Hidrologi Pendek Melaluai Identifikasi potensi Airtanah dan Aplikasi Sumur Resapan Setempat di Pondok Pesantren Darussalam Dusun Belungkulon Desa Sambongbangi Kecamatan Kradenan Kabupaten Grobogan. Surakarta: IbM LPPM UNS.

Legowo, B., \& Wahyuningsih, D. (2016). Developing a playground as catchment area in effort to maintaining groundwater in Jaten village of Karanganyar. Journal of Physics: Conference Series, 50-62.

Ulya, A., \& Djoko Marsono, B. (2014). Perencanaan SPAL dan IPAL Komunal kabupaten Ngawi (Studi Kasus Perumahan Karangtengah Prandon, Perumahan Karangsari dan Kelurahan Karangtengah). Jurnal Teknik POMITS, 157-161.

Wardoyo, P. (2019, Mei 12). https://joglosemarnews.com. Retrieved 1 Februari, 2020, from https://joglosemarnews.com:

https://joglosemarnews.com/2019/05/suspec t-pasien-dbd-karanganyar-capai-535-kasusdinas-kesehatan-karanganyar-imbau-wargatak-buru-buru-minta-fogging/ 